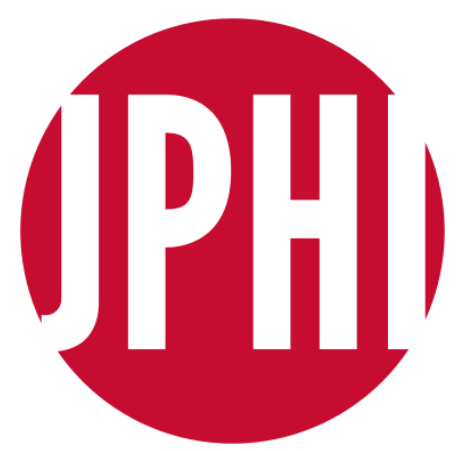

Jurnal Penegakan Hukum Indonesia (JPHI)

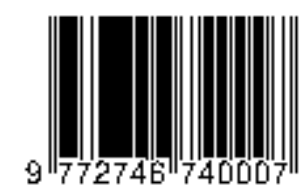

E-ISSN: 2746-7406

\section{ITIKAD BAIK DALAM PENDAFTARAN MEREK: STUDI PERLINDUNGAN HUKUM PEMILIK MEREK TERKENAL DI INDONESIA}

\author{
${ }^{[1]}$ Medisita Nurfauziah Istiqmalia \& \\ ${ }^{[2]}$ Iwan Erar Joesoef
}

Universitas Pembangunan Nasional Veteran Jakarta

Jl. R.S Fatmawati Pondok Labu Jakarta Selatan

${ }^{[1]}$ Email: medisita17@gmail.com

${ }^{[2]}$ Email: iwan.erar@gmail.com

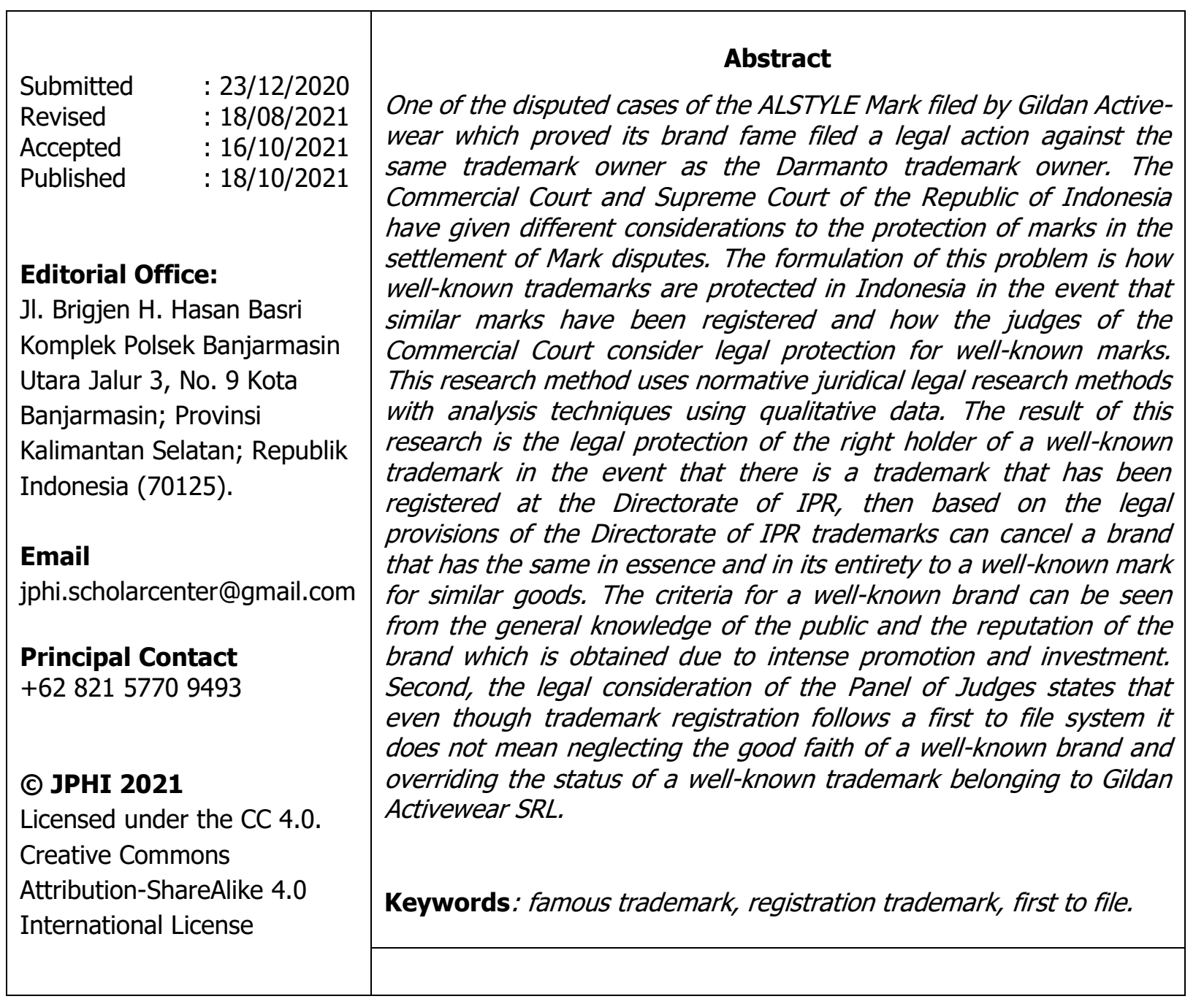




\begin{tabular}{|l|l|}
\hline \multicolumn{1}{|c|}{ Abstrak } \\
Salah satu perkara sengketa Merek ALSTYLE yang diajukan oleh \\
Gildan Active-Wear yang membuktikan keterkenalan mereknya \\
mengajukan upaya hukum terhadap pemilik merek yang sama \\
dengan pemilik merek Darmanto Adapun Pengadilan Niaga dan \\
Mahkamah Agung RI telah memberikan pertimbangan yang berbeda \\
terhadap perlindungan merek dalam penyelesaian sengketa Merek. \\
Rumusan masalah ini adalah bagaimana perlindungan merek terkenal \\
di Indonesia dalam hal terdapat merek serupa yang telah terdaftar \\
dan bagaimana pertimbangan hakim Pengadilan Niaga dalam \\
memberikan perlindungan hukum terhadap merek terkenal. Metode \\
Penelitian ini menggunakan metode penelitian hukum yuridis normatif \\
dengan teknik analisis menggunakan data kualintatif. Hasil penelitian \\
ini adalah perlindungan hukum terhadap pemegang hak atas merek \\
terkenal dalam hal terdapat merek yang sudah terdaftar di direktorat \\
HKI maka berdasarkan ketentuan hukum merek Direktorat HKI dapat \\
membatalkan merek yang mempunyai beberapa persamaan pada \\
pokok dan keseluruhannya terhadap merek terkenal untuk barang \\
sejenis. Kriteria merek terkenal dapat diketahui dari pengetahuan \\
umum masyarakat serta reputasi merek tersebut yang terkandung \\
karena promosi dan investasi yang gencar. Kedua, pertimbangan \\
hukum Majelis Hakim menyatakan meskipun pendaftaran merek \\
menganut sistem first to file bukan berarti Mengesampingkan itikad \\
baik merek terkenal dan mengesampingkan status merek terkenal \\
milik Gildan Activewear SRL. \\
Kata kunci: merek terkenal, pendaftaran merek, first to file. \\
\hline
\end{tabular}

\section{PENDAHULUAN}

Strategi bisnis dalam perdagangan semakin bersaing sehungga memicu pelaku usaha untuk memecahkan persoalan tentang bagaimana memasarkan suatu produk barang atau jasa dengan baik dengan menentukan kualitas yang memiliki standar mutu yang baik, tetapi juga bagaimana suatu merek barang atau jasa yang dimilikinya dapat diberikan perlindungan atau diproteksi dari kompetitor pelaku usaha lainnya. Oleh karena itu kompetisi dalam bisnis tidak hanya berupa bagaimana memperoleh perhatian dari konsumen, namun juga bersaing dalam suatu merek yang memiliki nilai dalam suatu produk atau jasa yang diperdagangkan. Merek dengan nama yang menarik dan menjadi pengetahuan umum yang sangat luas bagi masyarakat dan tentunya menjadi keinginan para pelaku usaha agar produk barang atau jasa miliknya juga mudah diingat dan dikenali oleh setiap konsumen yang membelinya. ${ }^{1}$

\footnotetext{
${ }^{1}$ Zainal Arifin \& Muhammad Iqbal, 'Perlindungan Hukum Terhadap Hak Merek Yang Terdaftar', Ius Constituendum, 5.1 (2020), 47.
} 
Merek adalah salah satu dari kekayaan intelektual yang dilindungi dalam perdagangan bisnis selain hak cipta, paten, desain industri, desain tata letak sirkuit terpadu, rahasia dagang, varietas tanaman, rahasia dagang, dan indikasi geografis. Merek ditunjukkan untuk kekayaan intelektual berupa tanda yang diperlihatkan pada barang atau jasa yang diperdagangkan untuk membedakan barang atau jasa yang dibuat dan dihasilkan oleh pihak lain. ${ }^{2}$

Pasal 1 angka 1 Undang-Undang Nomor 20 Tahun 2016 tentang Merek dan Indikasi Geografis (selanjutnya disebut UU Merek dan Indikasi Geografis), mendefinisikan merek sebagai tanda yang dapat ditampilkan secara grafis berupa gambarl ogo, nama, kata, huruf, angka, susunan warna, dalam bentuk 2(dua) dimensi dan/atau 3 (tiga) dimensi, suara, hologram, atau kombinasi dari 2 (dua) atau lebih unsur tersebut untuk membedakan barang dan/atau jasa yang diproduksi oleh orang atau badan hukum dalam kegiatan perdagangan batang dan/atau jasa. Berdasarkan ketentuan tersebut maka dapat dibedakan dalam 2 (dua) hal yang menyatakan sebagai berikut: ${ }^{3}$

1. Merek tradisional/konvensional, adalah yang membentuk gambar, logo, nama, kata, huruf, angka, susunan warna atau merek yang megambil bentuk 2 (dua) dimensi; dan

2. Merek non tradisional/media elektronik, yaitu merek yang berupa suara, merek 3 (tiga) dimensi, atau merek hologram.

Merek memiliki hak ekslusif yang diberikan oleh negara, untuk itu pelaku usaha wajib melakukan pendaftaran merek di direktorat merek. Agar hak atas merek tersebut mendapat perlindungan dan pengakuan dari negara, maka pemilik merek harus mendaftarkan pada negara. Jika suatu merek tidak didaftarkan maka merek tersebut tidak akan dilindungi oleh negara. Konsekuensinya merek tidak didaftarkan tersebut dapat digunakan oleh setiap orang. ${ }^{4}$

Pendaftaran merek harus ditolak oleh Dirjen HKI Direktorat Merek bila merek

\footnotetext{
2 Thoyyibah Bafadhal, 'Perlindungan Hukum Hak Merek Terkenal Di Indonesia: Kasus IKEA', Jurnal Hukum, 1.1 (2018), 25.

3 Nurul Hidayati \& Naomi Yuli Ester S, 'Urgensi Perlindungan Merek Melalui Protokol Madrid (Treadmark Protection Urgency Through The Madrid Protocol)', Jurnal Legislasi Indonesia, 14.2 (2017), 173.

${ }^{4}$ Agung Sujatmiko, 'Tinjauan Filosofis Perlindungan Hak Milik Atas Merek', Jurnal Media Hukum, 18.2 (2011), 177.
} 
yang dimohonkan mengandung itikad tidak baik, memiliki persamaan pada pokoknya dengan merek lain yang telah didaftar atau merek terkenal. ${ }^{5}$ Pendaftaran hak atas merek menganut asas first to file system ${ }^{6}$ yakni asas ini menyatakan pihak yang mendaftarkan merek terlebih dahulu dianggap sebagai pemilik merek yang sah. Pendaftaran merek juga menganut sistem konstitutif, yaitu hak atas merek yang diberikan apabila terjadi pendaftaran merek, sehingga terhadap pihak yang pertama terdaftar mendapatkan perlindungan hukum.

Meskipun syarat first to file system diterapkan bagi setiap pendaftar juga harus menerapkan prinsip itikad baik terhadap merek yang didaftarkan sebagaimana Pasal 21 angka (3) UU Merek dan Indikasi Geografis menyatakan terkait syarat yang wajib terdaftar pada Direktorat Jenderal HKI yaitu: "Permohonan ditolak jika diajukan oleh pemohon yang beritikad tidak baik. Ketentuan Pasal 21 ayat (3) UU Merek dan Indikasi Geografis dalam sistem pendaftaran Konstitutif tetapi tetap asasnya melindungi pemilik yang beritikad baik. Hanya permintaan yang diajukan oleh pemilik merek yang beritikad baik saja yang dapat diterima untuk didaftarkan. Dengan demikian aspek perlindungan hukum tetap diberikan kepada merek yang beritikad baik. ${ }^{7}$ Penjelasan Pasal 21 angka (3) UU Merek dan Indikasi Geografis menyatakan kualifikasi pemilik yang beritikad baik salah satunya adalah pemilik merek terkenal yang dapat diketahui dengan pengetahuan dasar masyarakat dalam mengenali merek di bidang usaha tersebut.

Merek terkenal terutama merek asing yang sering dipalsukan atau minimal pelaku usaha lokal dengan sengaja membonceng ketenaran dari merek asing terkenal tersebut karena nilai ekonomis dari digunakanya merek asing yang terkenal sangatlah tinggi. Akibatnya pemilik merek yang sah merasa dirugikan atas reputasi yang telah dibangun susah payah selama bertahun-tahun dengan tidak biaya yang sedikit. Kendatinya tidak hanya kepentingan dari merek terkenal saja yang dirugikan namun juga konsumen yang telah dirugikan karena membeli produk yang juga tiruan dari aslinya yang menggunakan merek terkenal tersebut dengan eksepetasi akan

\footnotetext{
${ }^{5}$ Dendy Widya Chandra, 'Perlindungan Merek Terkenal Asing Yang Belum Terdaftar Di Indonesia (Studi Kasus Sengketa Merek KEEN)', Jurnal Notarius, 13.1 (2020), 313.

${ }^{6}$ Tomi Surya Utomo, Hak Kekayaan Intelektual (HKI) Di Era Globalisasi Sebuah Kajian Kontemporer (Yogyakarta: Graha Ilmu, 2010).

7 Ok Saidin, Aspek Hukum Hak Kekayaan Intelektual (Intellectual Property Rights), 9th edn (Jakarta: PT Raja Grafindo, 2016).
} 
sama kualitas mutu barang atau jasa dengan merek yang terkenal. ${ }^{8}$

Tetapi keadaan di lapangan pada praktik perlindungan merek terkenal, banyak dilakukan dengan modus pemboncengan reputasi merek terkenal tersebut. Para oknum mempunyai itikad tidak baik dengan membuat sebuah produk barang dan/atau jasa yang mempunyai tingkat kemiripan sangat tinggi dengan merek terdaftar sehingga para masyarakat awam dapat terkecoh akibat pemboncengan merek tersebut. Hal ini merugikan baik itu kepada konsumen, maupun produsen/ pemilik merek terkenal. Konsumen merasa dirugikan karena mendapatkan barang tidak sesuai dengan keinginan dan produsen/ pemilik merek terkenal yang sudah mendaftarkan mereknya di negara asal dapat dirugikan secara finansial dengan adanya oknum yang membonceng merek tersebut.

Praktiknya salah satu kasus perkara Nomor 999 K/Pdt.Sus-HKI/2019 antara Gildan Activewear SRL melawan Darmanto dan Direktorat Jenderal Hak Kekayaan Intelektual Cq Direktur Merek dan Indikasi Geografis. Kasus ini berawal Gildan Activewear SRL yang merupakan perseroan di Neltown yang memproduksi produk barang merek ALSTYLE Apparel \& Activewear, yang telah mengajukan permohonan pendaftaran merek atas merek ALSTYLE. Gildan Activewear SRL mengklaim sebagai pelaku usaha yang menggunakan pertama kali dan sebagai pemegang yang sah atas merek ALSTYLE dan berbagai variasinya yang telah terdaftar di berbagai negara seperti Korea Selatan, Jepang, Amerika, Canada, Meksiko, Australia, dan Uni Eropa.

Gildan Activewear SRL keberatan atas merek yang terdaftar milik Darmanto yang sudah yang terdaftar di Direktorat Jenderal HKI, kemudian mengajukan upaya hukum ke Pengadilan Niaga pada Pengadilan Negeri Jakarta Pusat dalam perkara Nomor 3/Pdt.Sus-Merek/2019/PN.Niaga.Jkt.Pst untuk memerintahkan Direkrot Jenderal HKI agar membatalkan merek ALSTYLE milik Darmanto. Pengadilan Niaga telah memutuskan dalam amar putusanya untuk menolak gugatan Gildan Activewear SRL. Kemudian berlandaskan putusan Pengadilan Niaga pada Pengadilan Negeri Jakarta Pusat kemudian upaya hukum diajukan oleh Gildan Activewear melalui perkara Nomor 999 K/Pdt.Sus-HKI/2019, Adapun Majelis Hakim Kasasi telah mengabulkan permohonan Kasasi Gildan Activewear SRL dalam sengketa merek, dan

\footnotetext{
8 Titon Slamet Kurnia, Perlindungan Hukum Terhadap Merek Terkenal Di Indonesia Pasca Perjanjian Trip's (Bandung: Alumni, 2011).
} 
memerintahkan agar Direktorat Jenderal HKI untuk membatalkan merek ALSTYLE.

Berdasarkan adanya inkonsistensi dari perkara Putusan Pengadilan Niaga Jakarta Pusat dan Putusan Mahkamah Agung, maka dalam hal tersebut peneliti tertarik untuk mengangkat permasalahan hukum di dalam jurnal penelitian yang berjudul "Itikad Baik pada Pendaftaran Merek: Studi Perlindungan Hukum Pemilik Merek Terkenal di Indonesia."

\section{RUMUSAN MASALAH}

Berdasarkan latar belakang masalah di atas, sehingga dapat dirumuskan suatu rumusan masalah yang diteliti yakni sebagai berikut:

1. Bagaimana pertimbangan Hakim Pengadilan Niaga dalam memberikan perlindungan hukum terhadap merek terkenal?

2. Bagaimana seharusnya perlindungan merek terkenal di Indonesia atas merek lain yang terdaftar pertama kali di Direktorat Merek?

\section{METODE PENELITIAN}

Metode yang dilakukan dalam penelitian ini dengan melakukan pendekatan metode penelitian yuridis normatif yaitu suatu penelitian yang mengacu pada normanorma, asas-asas yang ada di dalam peraturan perundang-undangan selain itu ketentuan yang diatur dalam perjanjian konvensi Paris dan Konvensi TRIPS sebagai perjanjian internasional dalam perlindungan merek terkenal yang dikaitkan dengan putusan-putusan sengketa merek yang dilakukan oleh merek luar negeri yang mendaftar ke Indonesia.

Sumber data yang digunakan oleh peneliti yaitu data sekunder yang mencakup seperti bahan hukum primer, bahan hukum sekunder, dan bahan hukum tersier. Jenis dan sumber data sekunder yang didapat antara lain. ${ }^{9}$ Bahan hukum primer yaitu meliputi peraturan perundang-undangan yang menyangkut tentang merek terdiri dari: Undang- Undang No. 20 Tahun 2016 tentang Merek dan Indikasi Geografis, Undang- Undang No. 7 Tahun 1994 tentang Pengesahan Pembentukan Organisasi Perdagangan Dunia (World Trade Organisation/ WTO), Paris Convention For The Protection of Industrial Property, Peraturan Menteri Hukum dan Hak Asasi

\footnotetext{
${ }^{9}$ Amiruddin dan Zainal Asikin, Pengantar Metode Penelitian Hukum (Jakarta: PT Raja Grafindo, 2010).
} 
Manusia Republik Indonesia Nomor 67 Tahun 2016 Tentang Pendaftaran Merek, Keputusan Menteri Kehakiman RI: M-03-HC.02.01 Tahun 1991, Convention TRIP'S/ TRIP's Agreement (Trade Related Intellectual Property Rights). Putusan Pengadilan Niaga pada Pengadilan Negeri Jakarta Pusat 3/Pdt.Sus-Merek/2019/PN.Niaga.Jkt.Pst dan Putusan Kasasi Mahkamah Agung Nomor 999 K/Pdt.Sus-HKI/2019. Sumber hukum sekunder merupakan sumber yang erat hubungannya dengan sumber hukum primer dan mampu membantu dalam memahami dan memberikan penjelasan mengenai sumber hukum primer, seperti buku - buku, rancangan undang - undang, hasil - hasil penelitian, atau pendapat pakar hukum tentang hak kekayaan intelektual dalam penelitian ini sengketa merek terkenal dan sumber hukum tersier bahan yang memberikan informasi, petunjuk maupun penjelasan terhadap bahan hukum primer dan bahan hukum sekunder, seperti kamus hukum, ensiklopedia, wilkipedia.

Teknik Analisis yang digunakan mengggunakan pendekatan analisis kualitatif. Data yang telah diperoleh akan disusun secara sistematis untuk mencari jawaban dan mendapatkan kesimpulan dengan cara menganalisa semua bahan hukum yang berkaitan dengan judul penelitian, serta dapat menguraikan dan memecahkan masalah tentang itikad baik dan pertimbangan hukum dalam perlindungan pendaftaran merek terkenal di Indonesia.

Penelitian ini dilakukan dengan pendekatan kajian dan analisis antara pengaturan hukum yang diatur pada hukum kekayaan intelektual dalam ruang lingkup pengaturan sistem pendaftaran merek dan perlindungan hukum baik terhadap merek asing yang terkenal atau merek yang terdaftar, di samping itu penelitian ini juga mengkaji doktrin para ahli hukum dan teori yang berhubungan dengan perlindungan merek terkenal di Indonesia dalam hal telah terdapat merek yang terdaftar. Teknis analisis ini menggunakan pendekatan kualitatif yang digunakan untuk mencari jawaban dan mendapatkan kesimpulan dengan cara menganalisa semua bahan hukum yang berkaitan dengan judul penelitian sehingga dapat memecahkan masalah yang diteliti dalam perlindungan merk terkenal di indonesia dalam hal telah terdapat merek yang terdaftar. 


\section{PEMBAHASAN}

\section{Pertimbangan Hakim Pengadilan Niaga dalam memberikan Perlindungan Hukum terhadap Merek}

Pada umumnya pengertian merek merupakan instrumen dari hak intelektual seseorang yang diawali dengan penemuan di bidang Hak Kekayaan Intelektual misalkan hak paten. Jika di dalam merek ada unsur ciptaan misalnya desain, logo atau huruf dan merek itu sendiri hanya terbatas pada penggunaan produk dan jasa yang ada di dalam pasaran dan mengandung nilai ekonomis. ${ }^{10}$

Dari beberapa kasus merek - merek terkenal mayoritas dalam ruang lingkup perdata baik yang dilakukan perseorangan atau badan usaha. Gugatan pembatalan merek berdasarkan Pasal 76 \& Pasal 77 UU Merek dan Indikasi Geografis landasanya bagi pihak yang berkepentingan yang didasari dengan merek terkenal yang beritikad baik dapat mengajukan pembatalan merek. Gugatan merek terkenal terhadap pembatalan merek diajukan kepada pengadilan niaga sedangkan untuk merek terkenal asing dilakukan di Pengadilan Niaga Jakarta Pusat yang terdapat di dalam Pasal 76 (ayat 3) UU Merek dan Indikasi Geografis. Apabila ada pihak yang keberatan terhadap putusan pengadilan niaga maka dapat mengajukan upaya hukum melalui kasasi dan apabila keberatan juga terhadap upaya kasasi maka dapat diajukan upaya hukum peninjauan kembali.

Berdasarkan perkara Nomor 999 K/Pdt.Sus-HKI/2019 tentang Pembatalan Merek, telah diajukan oleh Pemohon Kasasi Gildan Activewear SRL melawan Darmanto, yang mana Gildan Activewear membuktikan keterkenalan mereknya yang telah terdaftar di beberapa beberapa negara yang mana telah dipasarkan secara internasional termasuk di Indonesia melalui berbagai pihak ketiga yang memahami kualitas produk Gildan Activewear di Pasaran Indonesia, dan masyarakat serta konsumen di bidang usaha yang bersangkutan di berbagai negara besar di dunia. Kemudian promosi yang dilakukan oleh Gildan Activewear yang sangat gencar terutama di situs-situs website pabrikan pakaian dan tercantum di dalam Wikipedia tentang siapa pemegang dan pemilik merek ALSYTLE.

10 Sulastri Et.A1, 'Perlindungan Hukum Terhadap Merek (Tinjauan Terhadap Merek Dagang Tupperware Versus Tulipware)', Jurnal Yuridis, 5.1 (2018), 162. 
Perlindungan merek terkenal bagi barang dan/atau jasa sejenis telah dijelaskan dalam Pasal 21 UU Merek dan Indikasi Geografis, dan pada penjelasan umumnya dijelaskan secara jelas kriteria untuk menentukan bahwa merek Gildan Activewear yang tertera ALSYTLE merupakan merek terkenal, yakni pengetahuan umum masyarakat mengenai merek tersebut di bidang usaha yang bersangkutan, sebenarnya dengan adanya banyak promosi-promosi yang dilakukan dan banyak katalog-katalog serta informasi melalui media iklan sehingga masyarakat mengetahui merek tersebut benar merupakan merek Gildan Activewear. Selain itu di dalam penjelasan Pasal 21 ayat (1) huruf b dijelaskan terkait telah didaftarkanya merek ALSYTLE milik Gildan Activewar di beberapa negara dan hal tersebut sudah dibuktikan di dalam persidangan, namun di dalam penjelasan umum Pasal 21 ayat (1) huruf $b$ tersebut masih belum memberikan kepastian hukum terkait kriteria merek terkenal, karena ada di dalamnya yang menyatakan apabila hal tersebut belum dianggap memuaskan, Pengadilan Niaga dapat memerintahkan lembaga yang bersifat mandiri untuk dilakukannya survei guna memperoleh kesimpulan mengenai terkenal atau tidaknya Merek yang menjadi dasar penolakan.

Namun kedudukan hukum lembaga yang diperintahkan oleh Pengadilan Niaga untuk melakukan survey terkait merek terkenal yang bersifat mandiri tersebut serta kewajiban-kewajibannya, masih belum memberikan kepastian hukum terhadap merek terkenal. Dalam perkara ini Merek ALSYTLE milik Gildan Activewear mencirikan suatu merek terkenal, namun kendatinya alasan pertimbangan hukum Majelis Hakim Pengadilan Niaga Nomor 3/Pdt.SusMerek/2019/PN.Niaga.Jkt.Pst, masih memberikan perlindungan terhadap merek ALSYTLE yang terdaftar milik Darmanto.

Namun Adanya lembaga survey yang dibuat oleh Pemerintah dalam aturan untuk mengetahui kriteria merek terkenal masih sangat lemah diterakan dalam pembuktiannya, hal ini dikarenakan untuk mengetahui kriteria merek terkenal tidak hanya berdasarkan pengetahuan masyarakat, namun tingkat produktivitas pelaku usaha, serta pemasaran dan promosi yang gencar di beberapa Negara dan beberapa sengketa Pengadilan Merek yang mengakui keterkenalan merek, dan sebagainya yang masih perlu pembuktian berdasarkan fakta yang nyata.

Namun setelah Gildan Activewear mengajukan upaya hukum kasasi 
Mahkamah Agung dalam perkara Kasasi Mahkamah Agung Republik Indonesia Nomor 999 K/Pdt.Sus-HKI/2019 telah mengabulkan merek terkenal milik Gildan Activewear sebagai pemilik yang beritikad baik dan sah sebagai pemilik merek ALSYTLE.

Pasal 21 UU Merek dan Indikasi Geografis yang telah menentukan terkait kriteria merek terkenal dan penolakan terhadap merek terkenal untuk barang sejenis, saat ini sudah diatur terkait dengan Peraturan Menteri Hukum dan Hak Asasi Manusia No. 67 Tahun 2016 terkait Pendaftaran Merek, ketentuan tersebut mempertegas pengaturan terkait merek terkenal, adapun ketentuan tersebut diatur di dalam Pasal 16 ayat (2) Peraturan Menteri Hukum dan Hak Asasi Manusia No. 67 Tahun 2016 adapun bunyinya yakni sebagai berikut:

"Permohonan ditolak oleh Menteri dalam hal Merek yang dimohonkan mempunyai persamaan pada pokoknya atau keseluruhannya dengan:

a. Merek terdaftar milik pihak lain atau dimohonkan lebih dahulu oleh pihak lain untuk barang dan/atau jasa sejenis;

b. Merek terkenal milik pihak lain untuk barang dan/atau jasa sejenis;

c. Merek terkenal milik pihak lain untuk barang dan/atau jasa tidak sejenis yang memenuhi persyaratan tertentu; atau

d. indikasi geografis terdaftar."

Merek ALYSTLE yang menurut pihak Gildan Activewear telah meniru dan menjiplak mereknya yakni merek dari Darmanto yang juga memakai merek ALYSTLE, untuk menilainya tersebut maka dalam pembuktianya Majelis Hakim dapat menggunakan Pasal 17 Peraturan Menteri Hukum dan Hak Asasi Manusia No. 67 Tahun 2016, yang menentukan penolakan persamaan pada pokok dan keseluruhanya terhadap merek terkenal untuk barang sejenis, yang berbunyi sebagai berikut:

"Penilaian persamaan pada pokoknya sebagaimana dimaksud dalam Pasal 16 ayat (2) dilakukan dengan memperhatikan kemiripan yang disebabkan oleh adanya unsur yang dominan antara Merek yang satu dengan Merek yang lain sehingga menimbulkan kesan adanya persamaan, baik mengenai bentuk, cara penempatan, cara penulisan atau kombinasi antara unsur, maupun persamaan bunyi ucapan, yang terdapat dalam Merek tersebut." 
Pengadilan dapat mengacu ketentuan yang dimaksud untuk membatalkan merek yang sudah terdaftar di Direktorat Merek yang mana setelah dibuktikan keterkenalan merek kemudian dikaitkan dengan Pasal 17 Peraturan Menteri Hukum dan Hak Asasi Manusia No. 67 Tahun 2016 dengan memperhatikan kemiripan yang disebabkan adanya unsur yang dominan dalam merek ALSYTLE yang menyerupai baik mengenai bentuk, cara penempatan, cara penulisan atau kombinasi antara unsur, maupun persamaan bunyi ucapan.

Berdasarkan ketentuan tersebut, yang menjadi perhatian oleh peneliti yakni siapa yang berhak untuk diberikan perlindungan terhadap merek yang juga sudah terdaftar di Direktorat Merek baik itu Merek ALSYTLE yang dimiliki oleh Gildan Active Wear yang diyatakan merek terkenal dalam permohonan gugatanya dengan Merek ALSYTLE milik darmanto.

Pertimbangan Majelis Hakim Pengadilan Niaga pada Pengadilan Negeri Jakarta Pusat Nomor 3/Pdt.Sus-Merek/2019/PN.Niaga.Jkt.Pst. telah menyatakan bahwa terhadap pemberian perlindungan hukum terhadap merek menganut azas first to file yang pada pokoknya perlindungan hukum bagi pemegang merek yang didasarkan pada pihak yang mendaftarkan terlebih dahulu dan Azas first to use yang pada pokoknya pemberian perlindungan hukum pada pemegang merek pada pihak pemilik dan pengguna pertama terhadap merek.

Majelis Hakim Pengadilan Niaga pada Pengadilan Negeri Jakarta Pusat mengacu pada ketentuan Pasal 1 angka 5 UU Merek dan Indikasi Geografis telah mencetuskan bahwa hak atas merek yang terdaftar untuk jangka waktu tertentu dengan menggunakan sendiri merek yang dimaksud atau memberikan izin kepada pihak lain. Majelis Hakim Pengadilan Niaga Pada Pengadilan Negeri Jakarta Pusat juga mengacu pada ketentuan Pasal 3 yang menganut azas first to file yaitu diberikannya perlindungan hukum terhadap pemegang merek kepada pihak yang mendaftarkan Merek tersebut terlebih dahulu. Setelah Majelis Hakim melihat yang berhak untuk diberikan perlindungan adalah Pemegang Merek atas nama Darmanto yakni Tergugat. Setelah disesuaikan nama Pemegang Darmanto terdaftar pada tanggal 23 Juli 2014 sedangkan merek ALSYTLE milik Gildan Active Wear terdaftar di Direktorat HKI baru terdaftar pada tanggal 2 Desember 2016. Maka Majelis hakim telah memberikan pertimbangan untuk menyatakan gugatan 
Gildan Active Wear haruslah ditolak.

Gildan Active Wear kemudian mengajukan upaya hukum Kasasi dalam perkara Kasasi Mahkamah Agung Republik Indonesia Nomor 999 K/Pdt.SusHKI/2019, dalam hal ini Majelis Hakim Kasasi memberikan pertimbangan hukum yang berbeda dengan Putusan Pengadilan Niaga yang telah diputuskan terhadap Merek ALSYTLE yang mana Majelis Hakim Pengadilan Kasasi menyatakan terhadap Putusan Pengadilan Niaga telah salah menerapkan hukum karena menerapkan asas first to file secara mutlak tanpa memperhatikan iktikad tidak baik Tergugat/Termohon Kasasi serta tanpa alasan sah mengesampingkan status merek terkenal milik Gildan Active Wear. Majelis Hakim Kasasi juga mempertimbangkan persamaan untuk keseluruhannya dengan merek terkenal milik Gildan Active Wear yang telah didaftarkan oleh di berbagai negara, jauh sebelum Merek Milik Darmanto mendaftarkannya di Indonesia untuk barang sejenis.

Merek milik Gildan Active Wear yang mempunyai merek ALSYTLE ternyata membuktikan jika merek tersebut merupakan merek terkenal dan juga harus diberikan perlindungan hukum terhadap merek-merek yang tidak beritikad baik yang dengan sengaja berusaha mendompleng dan meniru keterkenalan merek tersebut agar konsumen tertarik pada mereknya. Berbagai yurisprudensi Putusan yurisprudensi justru melindungi merek terkenal, meskipun belum terdaftar di Negara Indonesia namun secara geografis pendaftaran merek sudah terkenal di berbagai negara dan telah terdaftar di berbagai negara, sebagaimana Kasus Nike dalam Putusan No. 220 PK/PDT/ 1986, meskipun belum terdaftar namun merek tersebut merupakan merek terkenal yang harus diberikan perlindungan hukum.

Perkara Nomor 999 K/Pdt.Sus-HKI/2019, terkait pembatalan merek ALSYTLE milik Darmanto, dapat dilihat merek Penggugat/Pemohon kasasi yang di dalam fakta hukum dijelaskan bahwa Pemilik Gildan Active Wear merupakan merek terkenal bahkan sejak didaftarkanya merek dari ALSYTLE dari Darmanto yang ternyata meniru dan menggunakan merek terkenal dan hanya unruk mendompleng keterkenalan merek ALSYTLE milik Gildan Active Wear. Merek ALSYTLE dari Darmanto jelas merupakan merek yang tidak beritikad baik seharusnya Direktorat HKI menolak dan membatalkan merek tersebut, hal ini 
melihat Gildan Active Wear yang telah mengeluarkan jerih payahnya atas produk merek tersebut.

Sehingga berdasarkan hal tersebut Pendaftaran merek ALSTYLE milik Darmanto dengan alasan merupakan pengguna pertama first to file dan telah didaftarkan terlebih dahulu di Indonesia tidak dapat dibenarkan, karena telah dibuktikan dengan sendirinya bahwa pendaftaran merek ALSYTLE milik Darmanto dilakukan dengan iktikad tidak baik yaitu telah meniru, atau membonceng atau menjiplak ketenaran dari merek terkenal Gildan Active Wear di Negara asalnya dan juga diberbagai Negara.

Dengan demikian maka asas first to file system yang diterapkan dalam UU Merek dan Indikasi Geografis bukan sebagai suatu landasan hukum bahwa merek yang didaftarkan pertama kali mendapatkan perlindungan hukum atas merekmerek lain yang sama atau menyerupai dengan merek yang didaftarkan. Apabila diketahui dalam pembuktiannya ternyata mereknya tersebut meniru merek terkenal yang beritikad baik dalam hal ini merek terkenal yang sejak dahulu sudah terdaftar di Negara asal, maka Direktorat Merek tetap dapat menolak atau menghapus merek yang pertama kali terdaftar di Direktorat

\section{Perlindungan Merek Terkenal di Indonesia atas Merek lain yang Terdaftar Pertama kali di Direktorat Merek}

Perlindungan hukum terhadap merek dalam sistem Indonesia menurut peneliti terbagi menjadi 2 (dua) yang harus mendapatkan perlindungan dalam pendaftaran merek yakni:

Merek yang mendaftarkan di Direktorat merek menurut Sistem Konstitutif (aktif) dengan doktrinnya "prior in filling" bahwa yang berhak atas suatu Merek adalah pihak yang mendaftarkan Mereknya, dikenal pula dengan asas "presumption of ownership". Jadi pendaftaran itu menciptakan suatu hak atas Merek tersebut. Pihak yang mendaftarkan dialah satu-satunya yang berhak atas suatu Merek dan pihak ke tiga harus menghormati hak si pendaftar sebagai hak mutlak. ${ }^{11}$ First to file diistilahkan sebagai sistem konstitutif yang mengharuskan adanya pendaftaran yang pertama kali bagi merek untuk memperoleh

\footnotetext{
${ }^{11}$ Muhamad Djumhana \& Djubaedillah, Hak Milik Intelektual, Sejarah, Teori, Dan Praktiknya Di Indonesia (Bandung: Citra Aditya Bakti, 2016).
} 
perlindungan sehingga akibat hukum hak merek didasarkan pada pendaftaran. ${ }^{12}$

Suatu Merek terkenal yang sudah menjadi pengetahuan umum masyarakat luas, dan memiliki tingkat penjualan yang tinggi serta telah terdaftar di beberapa negara, sering ditemukan merek terkenal ditiru berupa penggunaan persamaan pada keseluruhan dan pokoknya dengan memanfaatkan dan membonceng merek terkenal tersebut. ${ }^{13}$

Meskipun menganut sistem konstitutif (asas first to file) bukan berarti tidak memberikan perlindungan hukum terhadap merek terkenal yang beritikad baik dan dilindungi oleh Undang-Undang. Undang-Undang Merek dan Indikasi Geografis tidak memberikan definisi tentang merek terkenal. Namun merek terkenal mengandung makna menurut pengetahuan umum masyarakat. Ketentuan mengenai merek terkenal dalam Bahasa asing well known. Hakim senantiasa mengacu pada well known mark yang mengaitkan pada pasal 6 bis Konvensi Paris, namun Pasal 6 bis Konvensi Paris sendiri tidak memberikan definisi atau kriteria tentang merek terkenal dan diserahkan sepenuhnya pada masing-masing negara. ${ }^{14}$

Ketentuan mengenai merek terkenal Indonesia telah meratifikasi beberapa perjanjian internasional, sehingga Indonesia terhadap merek terkenal terikat untuk memberikan perlindungan hukum. Beberapa ketentuan yakni dimulai dengan diratifikasinya perjanjian Internasional dalam Keputusan Presiden Nomor 15 Tahun 1997 Tentang Pengesahan Konvensi Paris dan Undang-Undang Nomor 7 Tahun 1994 Tentan Pengesahan WTO dalam hal ketentuan merek terkenal diatur di dalam TRIPS, keterikatan Indonesia terhadap perlindungan merek, dalam Konvensi Paris Pasal 6Bis juncto ketentuan TRIPS Agreement Pasal 16 ayat (2) dan Pasal 16 ayat (3) yang pada prinsipnya menyatakant perlindungan hukum terhadap merek terkenal bila ada persamaan pada pokok dan keseluruhannya.

Indonesia juga telah tergabung dalam trademark law treaty berdasarkan Keputusan Presiden Nomor 17 Tahun 1997 tentang pengesahan trademark law

12 R. Murjiyanto, 'Konsep Kepemilikan Hak Atas Merek Di Indonesia (Studi Pergeseran Sistem Deklaratif Ke Dalam Sistem Konstitutif)', Jurnal Quia Iustum, 24.1 (2017), 56.

13 Natasha Ratulangi, 'Upaya Duta Merek Terkenal Skechers Terhadap Pelanggaran Merek Berdasarkan Undang-Undang Merek Indonesia', Jurnal Reformasi Hukum Trisakti, 1.1 (2019), 2.

${ }^{14}$ Indira Hastuti, 'Perlindungan Hukum Bagi Pemilik Merek Terkenal Berdasarkan Undang-Undang Nomor 20 Tahun 2016 Tentang Merek Dan Indikasi Geografis', Jurnal Hukum Dan Dinamika Masyarakat, 16.2 (2019), 177. 
treaty. Dalam ketentuan terkait dengan ciri-ciri merek terkenal diatur didalam WIPO, yang mana dalam merek terkenal dapat dilihat dari Tingkat pengetahuan atau pengakuan mengenai merek tersebut dalam sektor publik yang bersangkutan, Masa, jangkauan dan daerah geografis dari penggunaan merek, Masa, jangkauan, dan daerah geografis dari promosi merek, termasuk pengiklanan dan publisitas serta presentasi pada pameran dari barang - barang atau jasa merek tersebut, Masa dan daerah geografis dari setiap pendaftaran dan setiap aplikasi pendaftaran sampai pada satu tingkat sehingga merefleksikan penggunaan atau pengakuan merek, Catatan dari penegakan hukum yang berhasil atas hak yang melekat pada merek sampai pada suatu tingkat dimana merek tersebut diakui sebagai merek terkenal oleh pejabat yang berwenang, dan nilai yang berkaitan dengan merek tersebut. ${ }^{15}$

Definisi secara lengkap mengenai merek terkenal tidak terdapat di dalam Pasal 1 UU Merek dan Indikasi Geografis hanya memberikan pengaturan saja untuk melindungi merek terkenal, namun terkait perlindungan terhadap merek terkenal diatur secara khusus di dalam UU Merek dan Indikasi Geografis yang terdapat telah menyatakan pengaturan terkait perlindungan hukum pada merek terkenal yang terdapat di dalam 21 ayat (1) UU Merek dan Indikasi Geografis sebagai berikut:

1) Permohonan ditolak jika Merek tersebut mempunyai persamaan pada pokoknya atau keseluruhannya dengan:

a. Merek terdaftar milik pihak lain atau dimohonkan lebih dahulu oleh pihak lain untuk barang dan/atau jasa sejenis;

b. Merek terkenal milik pihak lain untuk barang dan/atau jasa sejenis;

c. Merek terkenal milik pihak lain untuk barang dan/atau jasa tidak sejenis yang memenuhi persyaratan tertentu; atau

d. Indikasi Geografis terdaftar.

Sementara, itu di dalam UU merek dan indikasi geografis di dalam Penjelasan Pasal 21 ayat (1) huruf b UU Merek dan Indikasi Geografis tersebut dijelaskan terhadap merek terkenal untuk barang sejenis, adapun pendapatnya yang berbunyi:

"Penolakan Permohonan yang mempunyai persamaan pada pokoknya atau keseluruhan dengan Merek terkenal milik pihak lain untuk barang dan/atau jasa yang sejenis dilakukan dengan memperhatikan pengetahuan umum

\footnotetext{
${ }^{15}$ Achmad Zen Purba, Hak Kekayaan Intelektual Pasca TRIPS (Bandung: Alumni, 2005).
} 
masyarakat mengenai Merek tersebut di bidang usaha yang bersangkutan. Di samping itu, diperhatikan pula reputasi Merek tersebut yang diperoleh karena promosi yang gencar dan besar-besaran, investasi di beberapa negara di dunia yang dilakukan oleh pemiliknya, dan disertai bukti pendaftaran Merek dimaksud di beberapa negara. Jika hal tersebut belum dianggap cukup, Pengadilan Niaga dapat memerintahkan lembaga yang bersifat mandiri untuk melakukan survei guna memperoleh kesimpulan mengenai terkenal atau tidaknya Merek yang menjadi dasar penolakan."

Ketentuan terkait terhadap Pasal 21 UU Merek dan Indikasi Geografis ternyata telah diatur oleh pemerintah mengatur secara khusus terkait dengan merek terkenal dengan dikeluarkanya Peraturan Menteri Hukum dan Hak Asasi Manusia No. 67 Tahun 2016. mengenai kriteria merek terkenal diatur secara khusus sehingga merekmerek yang beritikad tidak baik berdasarkan Pasal 18 ayat (1) dan ayat (3) Peraturan Menteri Hukum Dan Hak Asasi Manusia No. 67 Tahun 2016 yaitu:

1) Kriteria penentuan Merek terkenal sebagaimana dimaksud dalam Pasal 16 ayat (2) huruf $b$ dan huruf $c$ dilakukan dengan memperhatikan pengetahuan umum masyarakat mengenai merek tersebut di bidang usaha yang bersangkutan.

2) Masyarakat sebagaimana dimaksud pada ayat (1) merupakan masyarakat konsumen atau masyarakat pada umumnya yang memiliki hubungan baik pada tingkat produksi, promosi, distribusi, maupun penjualan terhadap barang dan/atau jasa yang dilindungi oleh Merek terkenal dimaksud.

3) Dalam menentukan kriteria Merek sebagai Merek terkenal sebagaimana dimaksud pada ayat (1) dilakukan dengan mempertimbangkan:

a. tingkat pengetahuan atau pengakuan masyarakat terhadap Merek tersebut di bidang usaha yang bersangkutan sebagai Merek terkenal;

b. volume penjualan barang dan/atau jasa dan keuntungan yang diperoleh dari penggunaan merek tersebut oleh pemiliknya;

c. pangsa pasar yang dikuasai oleh Merek tersebut dalam hubungannya dengan peredaran barang dan/atau jasa di masyarakat;

d. jangkauan daerah penggunaan Merek;

e. jangka waktu penggunaan Merek;

f. intensitas dan promosi Merek, termasuk nilai investasi yang dipergunakan untuk promosi tersebut;

g. pendaftaran Merek atau permohonan pendaftaran Merek di negara lain;

h. tingkat keberhasilan penegakan hukum di bidang Merek, khususnya mengenai pengakuan Merek tersebut sebagai Merek terkenal oleh lembaga yang berwenang; atau

i. nilai yang melekat pada Merek yang diperoleh karena reputasi dan jaminan kualitas barang dan/atau jasa yang dilindungi oleh Merek tersebut 
Menurut Iman Sjahputera didalam bukunya hak kekayaan intelektual suatu pengantar mengatakan bahwa: ${ }^{16}$

"Suatu proteksi hukum merek yang terkenal tidak hanya meliputi barang barang sejenis, akan tetapi juga meliputi produk - produk yang tidak sama. Alhasil seseorang yang tidak beritikad tidak baik tidak diperkenankan untuk mendaftarkan dengan maksud "mendompleng" suatu merek terkenal".

Melihat di dalam perjanjian internasional TRIPS Agreements sebenarnya sudah memberikan syarat - syarat khusus tentang merek terkenal di dalam Pasal 16 ayat (3) TRIPS, aturan tersebut sebenarnya sudah bisa digunakan dalam hukum nasional, sehingga sudah tidak perlu diberikan syarat dengan membuat peraturan pemerintah apabila kita sudah meratifikasi perjanjian internasional. Untuk memberikan penjelasan terkait perlindungan hukum merek terkenal bagi barang dan/atau jasa yang tidak sejenis, peneliti membuat skema yang telah sesuai dengan sumber - sumber data yang telah ada, yaitu:

Gambar Skema

Perlindungan Hukum Merek Terkenal

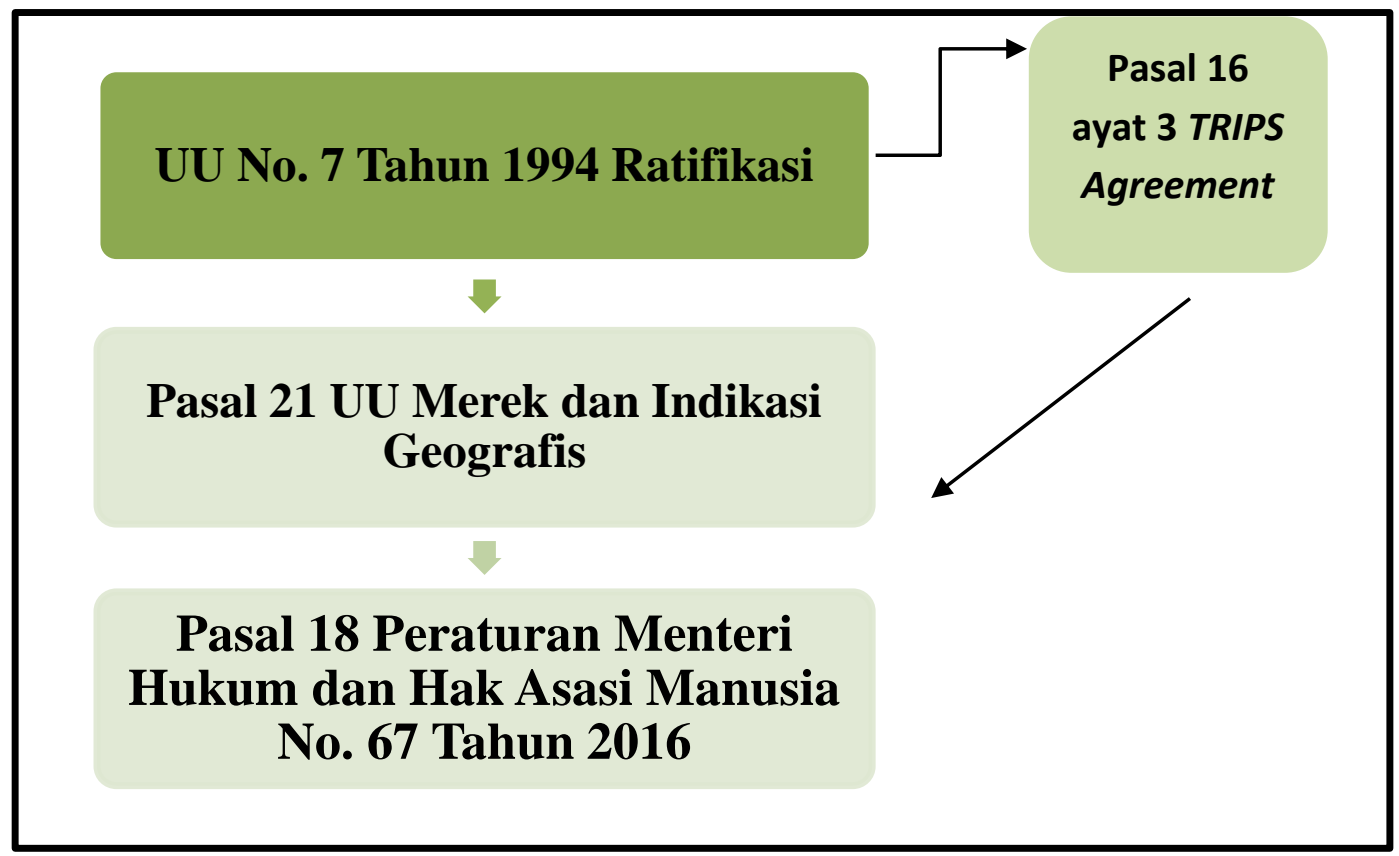

${ }^{16}$ Iman Sjahputra, Hak Atas Kekayaan Intelektual (Suatu Pengantar) (Jakarta: Harvindo, 2007). 
Bahwa perlindungan hukum merek terkenal berdasarkan proteksi kebijakan pemerintah untuk menyesuaikan hukum nasional dengan hukum internasional sudah dijalankan dengan baik, namum ada beberapa kelemahan, di dalam UU Merek yang harus segera direvisi untuk memberikan kepastian hukum bagi pemegang merek terkenal, salah satunya perluasan untuk melindungi merek terkenal baik itu barang dan jasa yang sama maupun barang dan/atau jasa yang tidak sejenis. Peneliti telah melakukan inventarisir kebijakan pemerintah dalam memberikan perlindungan hukum merek terkenal dalam bentuk aturan hukum berdasarkan tabel di bawah ini:

\begin{tabular}{|c|c|c|c|}
\hline $\begin{array}{c}\text { UU No. } 19 \text { Tahun } \\
1992\end{array}$ & $\begin{array}{c}\text { UU Merek No. } 14 \\
\text { Tahun } 1997\end{array}$ & $\begin{array}{l}\text { UU No. } 15 \text { Tahun } \\
2001\end{array}$ & $\begin{array}{l}\text { UU No. } 20 \text { Tahun } \\
2016\end{array}$ \\
\hline $\begin{array}{l}\text { - Memberikan } \\
\text { Kriteria Merek } \\
\text { Terkenal yang dapat } \\
\text { diketahui dari } \\
\text { pengetahuan umum } \\
\text { masyarakat } \\
\text { (Penjelasan } \\
\text { Umum Pasal } 6 \\
\text { ayat } 1 \text { UU No. } 19 \\
\text { Tahun 1992). } \\
\\
\text { - Perlindungan Merek } \\
\text { Terkenal yang tidak } \\
\text { terdaftar. } \\
\text { (Pasal } 56 \text { ayat } 3 \text { \& } \\
\text { Penjelasan } \\
\text { Umumnya UU No, } \\
\text { 19 Tahun 1992). }\end{array}$ & $\begin{array}{l}\text { - Penolakan } \\
\text { Pendaftaran yang } \\
\text { meniru merek } \\
\text { terkenal untuk barang } \\
\text { dan/atau jasa yang } \\
\text { sejenis. Ketentuan ini } \\
\text { berlaku juga untuk } \\
\text { barang dan/atau jasa } \\
\text { tidak sejenis yang } \\
\text { ketentuan akan diatur } \\
\text { melalui Peraturan } \\
\text { Pemerintah. (lihat } \\
\text { Pasal } 6 \text { ayat } 1 \text { \& } \\
\text { ayat } 4 \text { UU No. 14 } \\
\text { Tahun 1997) } \\
\text { - Kriteria Merek } \\
\text { Terkenal (lihat } \\
\text { Penjelasan Umum } \\
\text { Pasal } 1 \text { angka } 1 \text { UU } \\
\text { No. 14 Tahun } \\
\text { 1997). }\end{array}$ & $\begin{array}{l}\text { - Penolakan } \\
\text { Pendaftaran yang } \\
\text { meniru merek terkenal } \\
\text { untuk barang dan/atau } \\
\text { jasa yang sejenis. } \\
\text { Ketentuan ini berlaku } \\
\text { juga untuk barang } \\
\text { dan/atau jasa tidak } \\
\text { sejenis yang ketentuan } \\
\text { akan diatur melalui } \\
\text { Peraturan Pemerintah. } \\
\text { (lihat Pasal } 6 \text { ayat } 1 \\
\text { (b) \& ayat } 2 \text { UU No. } \\
\text { 15 Tahun } 2001 \text { ). } \\
\text { - Kriteria Merek } \\
\text { Terkenal (lihat } \\
\text { Penjelasan Umum } \\
\text { Pasal } 6 \text { ayat } \mathbf{1} \text { huruf } \\
\text { b UU No. } 15 \text { Tahun } \\
\text { 2001). }\end{array}$ & $\begin{array}{l}\text {-Penolakan } \\
\text { Pendaftaran merek } \\
\text { yang ditolak jika } \\
\text { merek mempunyai } \\
\text { persamaan dengan } \\
\text { merek terkenal utk } \\
\text { barang dan/atau jasa } \\
\text { sejenis/tidak sejenis, } \\
\text { ketentuan lebih lanjut } \\
\text { Peraturan Menteri } \\
\text { (lihat Pasal } \mathbf{2 1} \text { ayat } \\
\mathbf{1} \text { huruf b \& c UU No } \\
\mathbf{2 0} \text { Tahun 2016 } \\
\text { tentang Merek dan } \\
\text { Indikasi Geografis) }\end{array}$ \\
\hline
\end{tabular}

\section{PENUTUP}

\section{Kesimpulan}

1. Perlu adanya perlindungan hukum terhadap pemegang hak atas merek terkenal dalam hal telah terdaftarnya merek tersebut di Direktorat HKI maka berdasarkan ketentuan hukum merek yang diatur di dalam Pasal 21 ayat (1) huruf (b) UU Merek dan Indikasi Geografis, Direktorat HKI dapat menyanggah permohonan pendaftaran merek apabila mempunyai persamaan pada pokok dan keseluruhannya terhadap merek terkenal untuk barang sejenis. Kriteria merek 
terkenal dapat diketahui dari pengetahuan umum dan popularitas di masyarakat serta reputasi merek tersebut yang diperoleh karena promosi dan investasi yang gencar serta pendaftaran merek di berbagai negara dan waktu penggunaan merek, volume penjualan barang, maupun nilai-nilai yang telah melekat pada merek yang diperoleh karena pengetahuan umum masyarakat, reputasi, dan jaminan kualitas barang dan/atau jasa yang telah dilindungi dalam regulasi Merek sebagaimana ketentuan Peraturan Menteri Hukum Dan Hak Asasi Manusia No. 67 Tahun 2016. Ketentuan perjanjian ratifikasi internasional yang telah diratifikasi oleh Indonesia dalam Keputusan Presiden Nomor 17 Tahun 1997 tentang pengesahan trademark law treaty, Keputusan Presiden Nomor 2415 Tahun 1979 Tentang Pengesahan Konvensi Paris, UU Nomor 7 Tahun 1994 Tentang Pengesahan TRIPS Agreement yang salah satu tujuanya untuk memberikan perlindungan hukum terhadap merek terkenal.

2. Pertimbangan Majelis Hakim Kasasi Nomor 999 K/Pdt.Sus-HKI/2019 telah menyatakan merek ALSYTLE milik Gildan Activewear SRL telah membuktikan keterkenalan merek aslinya sedangkan merek ALSYTLE milik Darmanto, sehingga Majelis Hakim Kasasi menyatakan kesalahan penerapan putusan Pengadilan Niaga pada Pengadilan Negeri Jakarta Pusat Nomor 3/Pdt.SusMerek/2019/PN.Niaga.Jkt.Pst yang hanya menerapkan asas first to file sistem secara mutlak tanpa memperhatikam itikad baik dan mengesampingkan status merek terkenal milik Gildan Activewear SRL.

\section{Saran}

1. Direktorat Kekayaan Intelektual Merek perlu memberikan prioritas terhadap merek terkenal dengan cara memberikan langkah preventif pada siapapun pelaku usaha baik yang belum dan sudah terdaftar untuk dilakukan penghapusan merek jika diketahui adanya merek terkenal yang sudah terdaftar.

2. Bagi Pengadilan yang menangani sengketa merek agar dapat memberikan kepastian hukum terhadap upaya yang dilakukan oleh merek terkenal yang harus diberikan perlindungan hukum meskipun ada merek yang sudah terdaftar namun harus menolak jika merek yang terdaftar tersebut ternyata merek yang tidak 
beritikad baik dan meniru keterkenalan merek atas barang atau jasa.

\section{DAFTAR PUSTAKA}

\section{Buku :}

Amiruddin dan Zainal Asikin. 2010. Pengantar Metode Penelitian Hukum. Jakarta: PT Raja Grafindo.

Djumhana, Muhamad dan Djubaedillah. 2016. Hak Milik Intelektual, Sejarah, Teori, dan Praktiknya di Indonesia. Bandung: Citra Aditya Bakti.

Purba, Achmad Zen Umar. 2005. Hak Kekayaan Intelektual Pasca TRIPS. Bandung: Alumni.

Saidin, Ok. 2016. Aspek Hukum Hak Kekayaan Intelektual (Intellectual Property Rights). Jakarta: PT. Raja Grafindo. Cetakan ke-9.

Sjahputra, Iman. Hak Atas Kekayaan Intelektual (Suatu Pengantar). Jakarta: Harvindo.

Titon Slamet Kurnia, Perlindungan Hukum Terhadap Merek Terkenal di Indonesia Pasca Perjanjian TRIP's, Bandung: Alumni, 2011.

Tomi Surya Utomo, Hak Kekayaan Intelektual (HKI) Di Era Globalisasi Sebuah Kajian Kontemporer, Yogyakarta: Graha Ilmu, 2010.

\section{Peraturan Perundang-Undangan:}

Undang-Undang Republik Indonesia Nomor 7 Tahun 1994 Tentang Pengesahan Agreement Establshing The World Trade Organization (Persetujuan Pembentukan Organisasi Perdagangan Dunia).

Undang-Undang Republik Indonesia Nomor 20 Tahun 2016 Tentang Merek dan Indikasi Geografis

Keputusan Presiden Nomor 15 Tahun 1997 Tentang Pengesahan Paris Convention for the Protection of Industrial Property and Convention Establishing the World Intelectuall Property Organization.

Keputusan Presiden Nomor 17 Tahun 1997 Tentang Pengesahan Trademark Law Treaty.

Peraturan Menteri Hukum Dan Hak Asasi Manusia No. 67 Tahun 2016 Tentang Pendaftaran Merek.

\section{Jurnal dan Publikasi Lainnya:}


Arifin, Zainal dan Muhammad Iqbal. 2020. Perlindungan Hukum Terhadap Merek Yang Terdaftar. Jurnal Ius Constituendum. Vol. 5., No. 1. April 2020.

Bafadhal, Thoyyibah. 2018. Perlindungan Hukum Terhadap Merek Terkenal di Indonesia: Kasus IKEA. Undang: Jurnal Hukum. Vol. 1., No.1. April 2018.

Chandra, Dendy Widya, et.al. 2020. Perlindungan Merek Terkenal Asing Yang Belum Terdaftar di Indonesia (Studi Kasus Sengketa Merek KEEN). Jurnal Notarius. Vol. 13., No. 1. Maret 2020.

Hastuti, Indira. 2019. Perlindungan Hukum Bagi Pemilik Merek Terkenal Berdasarkan Undang-Undang Nomor 20 Tahun 2016 Tentang Merek dan Indikasi Geografis. Jurnal Hukum dan Dinamika Masyarakat. Vol. 16., No. 2. April 2019.

Hidayati, Nurul dan Naomi Yuli Ester S. 2017. Urgensi Perlindungan Merek Melalui Protokol Madrid (Trademark Protection Urgency Through the Madrid Protocol). Jurnal Legislasi Indonesia. Vol. 14., No. 2. Juni 2017.

Murjiyanto, R. 2017). Konsep Kepemilikan Hak Atas Merek Di Indonesia (Studi Pergeseran Sistem Deklaratif Ke Dalam Sistem Konstitutif"). Jurnal Quia Iustum. Vol. 24., Issue 1. Januari 2017.

Sujatmiko, Agung. 2011. Tinjauan Filosofis Perlindungan Hak Milik Atas Merek. Jurnal Media Hukum. Vol. 18., No. 2. Desember 2011.

Sulastri, et.al. 2018. Perlindungan Hukum Terhadap Merek (Tinjauan Terhadap Merek Dagang Tupperware Versus Tulipware). Jurnal Yuridis. Vol. 5., No. 1. Juni 2018.

Sulasytyawati, Dwi. 2014. Hukum Pajak Dan Implementasinya Bagi Kesejahteraan Rakyat. Salam: Jurnal Sosial dan Budaya. Vol. 1., No. 1. Juli 2014.

\section{Putusan Pengadilan :}

Putusan Pengadilan Niaga pada Pengadilan Negeri Jakarta Pusat Nomor 3/Pdt.SusMerek/2019/PN.Niaga.Jkt.Pst.

Putusan Kasasi Mahkamah Agung Republik Indonesia Nomor 999 K/Pdt.SusHKI/2019 